\title{
SOUTHERNMOST LOCALITY FOR ENDANGERED LIZARD, DAREVSKIA CLARKORUM (LACERTIDAE, SQUAMATA) FROM EASTERN BLACK SEA COAST OF TURKEY
}

\author{
Muammer Kurnaz*, Bilal Kutrup \\ Karadeniz Technical University, Turkey \\ *e-mail:mkurnaz@ktu.edu.tr
}

Received: 04.06.2018

\begin{abstract}
Darevskia clarkorum is an endangered species distributed within a restricted area in Georgia and Turkey. The study has presented a new locality in the Province of Gümüşhane for the species. As the new locality is about 40 $\mathrm{km}$ away from the known distribution area, it is important in terms of defining the southernmost distribution area and limited locality of species. The record of the new locality of Darevskia clarkorum reveals that the species also occurs outside coastal areas. Thus, the endangered species begins to inhabit inland provinces, too.
\end{abstract}

Key words: Darevskia clarkorum, Gümüşhane, morphology, new locality

Darevskia clarkorum (Darevsky \& Vedmederja, 1977) is a medium-sized lacertid lizard in the genus Darevskia (Arribas, 1997). It has a restricted distribution area along the coast of the eastern Black Sea Region of Turkey and Adzharia Region of Georgia. The population trend of the species is decreasing, and it is classified as Endangered (EN) according to the IUCN Red List of the Threatened Species (Tuniyev et al., 2009). The range extension of the species was from the Hopa in Artvin Province to Giresun Province in Turkey (Baran \& Atatür, 1998; Ilgaz, 2007). The known localities of the species were very scarce in this distribution area. After the description of the species, a few studies including taxonomy, morphology, distribution and ecology were performed about it (Franzen, 1990, 1991; Darevsky \& Tuniyev, 1997; Sindaco et al., 2000; Schmidtler et al., 2002; Ilgaz, 2007; Bülbül et al., 2016). The present study aims to add a new province and new locality to the distribution area of the species. The new locality represents the southernmost part of the distributional area (about $40 \mathrm{~km}$ away from the so far known distribution area) of the species. The new locality of the species reveals that the species is not only distributed to coastal provinces but also begins to inhabit inland provinces.

During the field study, four male specimens were collected from the locality Akocak, Gümüşhane (10 April 2018, GPS data: 40 $36^{\prime} \mathrm{N}$, $39^{\circ} 53^{\prime} \mathrm{E}$, about $1730 \mathrm{~m}$ a.s.1.) (Fig.). These four specimens were anesthetised with a ether, fixed with a $10 \%$ formaldehyde injection, and deposited in $70 \%$ ethanol. They were deposited in the Zoology Laboratory (Collection number: KZL-289 for Akocak) of the Department of Biology at the Faculty of Science, Karadeniz Technical University.
Morphometric, meristic and qualitative data were recorded following the systems of Ilgaz (2007). All pholidolial characters were examined under the stereomicroscope and all specimens' morphometric features were measured using a digital caliper with an accuracy of $0.1 \mathrm{~mm}$. All measured data were compared with studies by Darevsky \& Vedmederja (1977), Darevsky \& Tuniyev (1997) and Ilgaz (2007). The following pholidolial characteristics were evaluated: supraciliar granules (right - left, SCGa - SCGb), loreal plates back of postnasal plates and front of preocular plates (right - left, Loa - LOb), supraciliar plates (right - left, $\mathrm{SCPa}-\mathrm{SCPb}$ ), supralabial plates (right - left, SRLa - SRLb, number of labials both anterior and posterior to center of eye), sublabial plates (right - left, $\mathrm{SLPa}-\mathrm{SLPb}$ ), inframaxillar plates (right - left, $\mathrm{IMa}-\mathrm{IMb}$ ), transversal series of gular scales between inframaxillar symphysis and collar (MG), collar (C), supratemporals (right - left, STa - STb), ventral plates (transversal and longitudinal, TVP and LVP), femoral pores (right - left, $\mathrm{FPa}-\mathrm{FPb}$ ), subdigital lamellae in the 4th toe (right - left, SDLa - SDLb), transversal series of dorsal scales at the midbody (DS), and the number of preanal scales surrounding anals (PA1) and all plates surrounding anals (PA2).

The morphometric measurements in this study following: snout-vent length (SVL), tail length (TL), pileus width (PW), pileus length (PL), head width (HW), head length (HL), total body length (TBL). The habitat of the specimens from Akocak concerns a rocky area near the village road within broad-leaved bushes (Fig.).

The specimens were found during a day excursion between 13:00 and 13:30. The temperature was about $20^{\circ} \mathrm{C}$. 

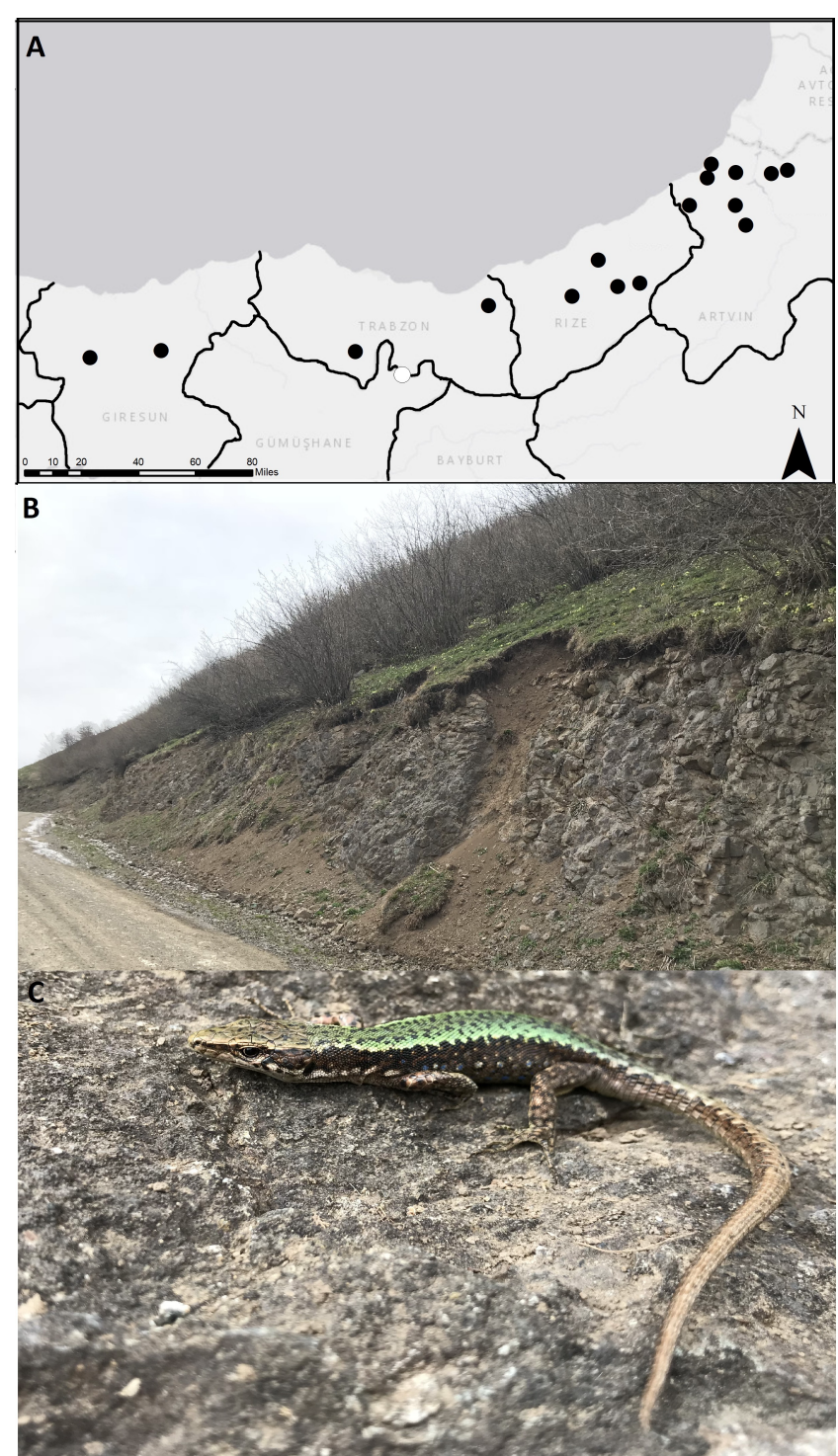

Fig. 1. A: Map showing the distribution area of Darevskia clarkorum in Turkey. Black circles represent the known distribution according to the literature and the white circle shows the new locality. B: The habitat of the D. clarkorum from Akocak. C: General view of a male specimen of $D$. clarkorum.

Pholidolial characteristics. Rostral and internasal plates were in contact in all specimens. The occipital plate was in contact with interparietal plate in all specimens. The postnasal plate was single on each side in all four specimens. The masseteric plate was reduced in one specimen ( $25 \%$ ) and it is present in three specimens (75\%). The row of supraciliar granules was discrete. SCP was six $(100 \%)$ in both sides in all specimens. LOs were always two on both sides of the head in all specimens. In all specimens, a large and clear tympanicum was present on both sides of the head. Four supraocular plates were present on both sides of the head in all specimens. SRPs were (100\%) in the left and right side of the head of the all specimens. SLPa was five $(50 \%)$ in two specimens and six $(50 \%)$ in two specimens. SLPb was six (75\%) in three specimens and six $(25 \%)$ in one specimen. STs were large and broad. STa was two $(50 \%)$ in two specimens and three $(50 \%)$ in two specimens. STb was two $(25 \%)$ in one specimen and three $(75 \%)$ in three specimens. IMs were always 5-5 (100\%), and the first three of them were in contact in all specimens. Collars were always smooth-edged in all specimens $(100 \%)$. Dorsal body scales were small and smooth. Subdigital lamellae on $4^{\text {th }}$ toe was smooth. The anal plate was single in all specimens. PA1 was usually two (75\%) and eight (25\%).

Morphometric measurements. While the maximum TBL for the male specimens was 227.04 $\mathrm{mm}$, the maximum SVL for male were $58.35 \mathrm{~mm}$. Descriptive statistics of pholidolial characteristics and morphometric measurements of specimens collected from Akocak are shown in Table 1.

Colour-Pattern. The top of the head was brown or greenish brown with small spots on all plates. The lateral sides of the head, especially the temporal bands, were black. The colour of the supralabial plates was light brown. The colour of the middle of the dorsum was generally green and brownish and it is black or dark brown on both lateral sides of the dorsum. There were blue spots along both lateral sides of the dorsum. The ventral region was generally light green and yellowish and blue spots were present at the margin of the ventral plates (Fig.).

The pholidolial characteristics and morphometric measurements of our specimens are nearly similar to the specimens used in the studies by Darevsky \& Vedmederja (1977), Darevsky \& Tuniyev (1997) and Ilgaz (2007). The comparison is given in Table 2.

In literature, the studies related to Turkish populations of $D$. clarkorum are mainly based on morphological investigations (Darevsky \& Vedmederja, 1977; Darevsky \& Tuniyev, 1997; Ilgaz, 2007). When we compared our results from the Akocak population to records in literature, we found slightly differences in some morphometric characters based on SVL and TL with the studies of Darevsky \& Tuniyev (1997) and Ilgaz (2007), while the characters were very different from the study by Darevsky \& Vedmederja (1977). Other pholidolial characters were nearly similar with those in the above mentioned literature. Only DS was lower and LVP was higher than from the studies in literature. Although our results were found similar to records of literature, the number of the specimens in our study was very low. More specimens should be investigated to evaluate the similarity of the Akocak population with other populations. Based on our findings, original descriptions of the species and data of the studies in literature, we conclude that our specimens belong to $D$. clarkorum. But our conclusion is not based on molecular data (yet). 
Table 1. Descriptive statistics of some pholidolial characteristics and morphometric measurements of Darevskia clarkorum collected from Akocak, Gümüşhane. For abbreviations, see text (n: number of samples; M: Median; Min: minimum value; Max: maximum value; SE: standard error)

\begin{tabular}{cccccccccccccc}
\hline Characters & $n$ & M & Mean & Min & Max & SE & Characters & n & M & Mean & Min & Max & SE \\
\hline SCGa & 4 & 5.5 & 5.00 & 3.00 & 6.00 & 0.71 & STb & 4 & 3 & 2.75 & 2.00 & 3.00 & 0.25 \\
SCGb & 4 & 5 & 4.75 & 3.00 & 6.00 & 0.63 & LVP & 4 & 28 & 27.75 & 27.00 & 28.00 & 0.50 \\
SCPa & 4 & 6 & 6.00 & 6.00 & 6.00 & 0.00 & TVP & 4 & 6 & 6.00 & 6.00 & 6.00 & 0.00 \\
SCPb & 4 & 6 & 6.00 & 6.00 & 6.00 & 0.00 & FPa & 4 & 16.5 & 16.25 & 15.00 & 17.00 & 0.48 \\
SRPa & 4 & 6 & 6.00 & 6.00 & 6.00 & 0.00 & FPb & 4 & 17 & 16.75 & 15.00 & 18.00 & 0.63 \\
SRPb & 4 & 6 & 6.00 & 6.00 & 6.00 & 0.00 & DS & 4 & 44 & 44.00 & 42.00 & 47.00 & 1.08 \\
SLPa & 4 & 5.5 & 5.50 & 5.00 & 6.00 & 0.29 & PA1 & 4 & 2 & 1.75 & 1.00 & 2.00 & 0.25 \\
SLPb & 4 & 6 & 5.75 & 5.00 & 6.00 & 0.25 & PA2 & 4 & 7 & 6.75 & 6.00 & 8.00 & 0.48 \\
SDLa & 4 & 26 & 25.75 & 25.00 & 27.00 & 0.48 & SVL & 4 & 57.13 & 57.11 & 56.22 & 58.35 & 4.29 \\
SDLb & 4 & 26 & 25.75 & 25.00 & 27.00 & 0.48 & TL & 3 & 91.1 & 113.69 & 79.15 & 170.82 & 28.77 \\
$\mathrm{IMa}$ & 4 & 5 & 5.00 & 5.00 & 5.00 & 0.00 & PW & 4 & 7.02 & 7.09 & 6.82 & 7.50 & 0.16 \\
$\mathrm{IMb}$ & 4 & 5 & 5.00 & 5.00 & 5.00 & 0.00 & PL & 4 & 12.81 & 12.47 & 10.32 & 13.92 & 0.76 \\
$\mathrm{MG}$ & 4 & 22 & 21.50 & 20.00 & 22.00 & 0.50 & HW & 4 & 9 & 9.20 & 8.80 & 10.01 & 0.28 \\
$\mathrm{C}$ & 4 & 7 & 7.00 & 6.00 & 8.00 & 0.41 & HL & 4 & 14.64 & 14.64 & 14.32 & 14.95 & 0.16 \\
$\mathrm{STa}$ & 4 & 2.5 & 2.5 & 2.00 & 3.00 & 0.29 & TBL & 3 & 170.50 & 170.52 & 136.26 & 227.04 & 28.47 \\
\hline
\end{tabular}

Table 2. Comparison of some pholidolial characteristics and morphometric measurements of our specimens with those given by Darevsky \& Vedmederja (1977), Darevsky \& Tuniyev (1997) and Ilgaz (2007). For abbreviations, see text (n: number of specimens; Range: extreme values, * the values are used for left side of the body)

\begin{tabular}{ccccccccc}
\hline & \multicolumn{2}{c}{ Darevsky \& Vedmederja (1977) } & \multicolumn{2}{c}{ Darevsky \& } & Tuniyev (1997) & \multicolumn{2}{c}{ Ilgaz (2007) } & \multicolumn{2}{c}{ This study } \\
\hline Characters & Mean & Range & Mean & Range & Mean & Range & Mean & Range \\
SVL & 65.4 & $62.0-69.0$ & 58.9 & $54.7-63.4$ & 59.3 & $44.4-67.0$ & 57.1 & $56.2-58.3$ \\
TL & 124.0 & $120.0-126.0$ & 107.1 & $101.0-120.0$ & 106.2 & $84.0-128.0$ & 113.7 & $79.1-170.8$ \\
PA1 & - & - & 2.6 & $2.0-3.0$ & 2.5 & $2.0-4.0$ & 1.7 & $1.0-2.0$ \\
PA2 & - & - & 9.1 & $7.0-10.0$ & 8.6 & $6.0-11.0$ & 6.7 & 6.08 .0 \\
FP & 18.6 & $16.0-20.0$ & 17.3 & $16.0-19.0$ & 17.9 & $14.0-21.0$ & 16.7 & $15.0-18.0$ \\
MG & 24.0 & $23.0-26.0$ & 22.4 & $21.0-24.0$ & 22.3 & $17.0-25.0$ & 21.5 & $20.0-22.0$ \\
SCG & 6.6 & $5.0-10.0$ & 6.1 & $5.0-8.0$ & 6.4 & $2.0-9.0$ & 4.7 & $3.0-6.0$ \\
DS & 51.0 & $49.0-51.0$ & 52.0 & $47.0-57.0$ & 48.7 & $44.0-55.0$ & 44.0 & $42.0-47.0$ \\
LVP & 23.0 & $22.0-25.0$ & 24.5 & $22.0-26.0$ & 23.6 & $21.0-26.0$ & 27.7 & $27.0-28.0$ \\
\hline
\end{tabular}

\section{Acknowledgements}

We thank Kemal Vehbi Imamoğlu for his assistance during the field study.

\section{References}

Arribas O.J. 1997. Morfología, filogenia y biogeografía de las lagartijas de alta montaña de los Pirineos. $\mathrm{PhD}$ Thesis. Cerdanyola del Vallès: Universitat Autònoma de Barcelona. 353 p.

Baran İ. Atatür M.K. 1998 Turkish Herpetofauna (Amphibians and Reptiles). Ankara: Ministry of Environment. 214 p. [In Turkish]

Bülbül U., Kurnaz M., Eroğlu A.İ., Koç H., Kutrup B. 2016. Body size and age structure of the endangered Clark's lizard (Darevskia clarkorum) populations from two different altitudes in Turkey. Amphibia-Reptilia 37: 450 456. DOI: 10.1163/15685381-00003073

Darevsky I.S., Vedmederja V. 1977. A new species of rock lizard Lacerta saxicola Eversmann group from north- eastern Turkey and adjoining regions of Adjaria. Proceedings of the Zoological Institute of the USSR Academy of Sciences 74: 50-54. [In Russian]

Darevsky I.S., Tuniyev B.S. 1997. A new lizard species from Lacerta saxicola group - Lacerta dryada sp. nov. (Sauria, Lacertidae) and some comments relative to Lacerta clarkorum Darevsky et Vedmederja, 1977. Russian Journal of Herpetology 4: 1-7.

Franzen M. 1990. Die Eidechsenfauna (Lacertidae) der Türkei. Die Eidechse 1(1): 3-9.

Franzen M. 1991. Beobachtungen zur phytophagen Ernährung von Lacerta rudis und Lacerta clarkorum. Die Eidechse 2(2): 22-23.

Ilgaz Ç. 2007. The Morphology, Taxonomy, and Distribution of Specimens of Darevskia clarkorum (Sauria: Lacertidae: Darevskia) Collected from Turkey's Eastern Black Sea Region. Turkish Journal of Zoology 31(4): 325-336.

Schmidtler J.F., Heckes U., Bischoff W., Franzen M. 2002. Höhenabhängige Merkmalsvariation bei Felseidechsen 
des Darevskia clarkorum (Darevsky \& Vedmederja, 1977) / D. dryada (Darevsky \& Tuniyev, 1997)-Komplexes: Ein Fall von klimaparalleler Pholidosevariation? Faunistische Abhandlungen Staatliches Museum für Tierkunde in Dresden 23(8): 141-156.

Sindaco R., Venchi A., Carpaneto G.M., Bologna M.A. 2000. The reptiles of Anatolia: A checklist and zoogeo- graphical analysis. Biogeographia 21: 441-554. DOI: 10.21426/B6110017

Tuniyev B., Ananjeva N.B., Agasyan A., Orlov N.L., Tuniyev S. 2009. Darevskia clarkorum. In: The IUCN Red List of Threatened Species 2009: e.T11117A114549398. DOI: 10.2305/IUCN.UK.2009. RLTS.T11117A3251827.en.

\title{
НАИБОЛЕЕ ЮЖНОЕ МЕСТОНАХОЖДЕНИЕ ИСЧЕЗАЮЩЕГО ВИДА DAREVSKIA CLARKORUM (LACERTIDAE, SQUAMATA) В ВОСТОЧНОЙ ЧАСТИ ЧЕРНОМОРСКОГО ПОБЕРЕЖЬЯ ТУРЦИИ
}

\author{
М. Курназ*, Б. Кутруп \\ Черноморский технический университет, Туриия \\ *e-mail:mkurnaz@ktu.edu.tr
}

\begin{abstract}
Darevskia clarkorum - исчезающий вид, распространенный на ограниченной территории в Грузии и Турции. Данная работа представляет новое местонахождение и провинцию (Гюмюшхане) для этого вида. Так как новая находка сделана в 40 км от ближайшего известного местонахождения, она важна для определения южной границы распространения этого вида. Новое местонахождение свидетельствует о том, что исчезающий вид распространен не только в прибрежной части ареала, но встречается и в провинциях, расположенных далеко от моря.
\end{abstract}

Ключевые слова: Darevskia clarkorum, Гюмюшхане, морфология, новое местонахождение 